\title{
Cytotoxic activity of the dichloromethane fraction from Vernonia scorpioides (Lam.) Pers. (Asteraceae) against Ehrlich's tumor cells in mice
}

T. Pagno, L.Z. Blind, M.W. Biavatti and M.R.O. Kreuger
Centro de Ciências da Saúde, Universidade do Vale do Itajaí, Itajaí, SC, Brasil

\author{
Correspondence \\ M.R.O. Kreuger \\ Centro de Ciências da Saúde \\ UNIVALI \\ 88302-202 Itajaí, SC \\ Brasil \\ Fax: +55-47-3348-7477 \\ E-mail: mariaregina@univali.br \\ Research supported by grants from \\ the Santa Catarina Government. \\ Received March 30, 2006 \\ Accepted August 23, 2006
}

\begin{abstract}
Vernonia scorpioides has been widely used in Brazil to treat skin problems and chronic wounds, such as ulcers of the lower limbs and diabetic lesions. In the present study, we investigated the effect of a dichloromethane (DCM) fraction of $V$. scorpioides leaf extract on Ehrlich ascitic and solid tumor-bearing mice. The animals were treated once a day with the DCM fraction at a concentration of $5 \mathrm{mg} / \mathrm{kg}$, administered ip during and after the development of the tumor. The lifespan, weight, number and type of leukocytes, number of tumor cells, volume of solid and ascitic tumors were measured. The development of the tumor with pre-treated tumor cells in vitro with the DCM fraction (5 $\mathrm{mg} / \mathrm{kg}$ ) was analyzed and the animals were sacrificed after 7 days. The DCM fraction $(5 \mathrm{mg} / \mathrm{kg})$ totally inhibited tumor development when in direct contact with tumor cells, and also ascitic tumor development with in vitro treatment or when administered ip, in loco (after 7 days). Animals treated with the DCM fraction increased their lifespan ca. 2 weeks and maintained their body weight for 30 days. When applied immediately after the inoculation of the tumor cells in vivo, it totally abolished tumor development, with tumor development only decreasing when treatment was started 3 days after the tumor challenge. These data suggest an antineoplastic activity of the fraction. Oral or $i p$ administration of DCM fraction $(5 \mathrm{mg} / \mathrm{kg}$ ) for 7 days did not reduce the solid tumor volume. The cytotoxic activity described here differs from the conventional immune suppressing profile of standard chemotherapy because it increases neutrophil influx to the peritoneal cavity. These results show that, besides exhibiting a tumoricidal activity, the DCM fraction also exhibits inflammatory activity.
\end{abstract}

\section{Introduction}

Vernonia scorpioides (Lam.) Pers., Asteraceae, popularly known as piracá, enxuga or erva-de-São-Simão in Portuguese, is very common in Brazil, and usually grows in poor
Key words

- Vernonia scorpioides

- Leaf extract

- Antitumoral

- Ehrlich ascitic tumor

- Neutrophils 
and its derived chloroform and hexane fractions have shown fungicidal activity (2), moderate bactericidal activity and mild wound healing effects (3).

There are an estimated 200 species of Vernonia in Brazil, some of which are traditionally ingested to treat gastrointestinal disorders (4), such as the fresh macerated leaves of $V$. condensate, commonly known as Indian Bitterness (fel-de-bugre, fel-de-índio or alumã in Portuguese). Recent studies focusing on the anti-inflammatory $(5,6)$, antipyretic (7), anticancer (8-11), and antimalarial $(12,13)$ activities of several Vernonia species have been published.

The genus Vernonia produces characteristic compounds such as sesquiterpene lactones, with several reported biological activities, such as fungistatic (14), and cytotoxic activities $(15,16)$ and also acts as a smooth muscle relaxant (17). Some other compounds have been isolated from Vernonia, such as flavonoids (18), steroids (19) and polysaccharides (20).

In a previous study by our group (3), a pro-inflammatory profile was observed in healthy skin tissue, which prompted an investigation of effect of the crude extract on Ehrlich ascitic and solid tumors in mice. The promising antitumoral result preliminarily obtained with the crude leaf extract led us to partition it in order to obtain fractions of increasing polarity, namely: hexane, dichloromethane (DCM), ethyl acetate and aqueous fractions, tested at $200 \mathrm{mg} / \mathrm{kg}$. Of these, the DCM fraction showed the highest cytotoxicity against tumor cells, especially when applied in loco to the developing tumor.

In the present study, we investigated the effect of the DCM fraction obtained after liquid-liquid partition of the crude hydroalcoholic extract of the $V$. scorpioides leaf on Ehrlich ascitic and solid tumor-bearing mice. The animals were treated with the DCM fraction at a concentration of $5 \mathrm{mg} / \mathrm{kg}$ once a day, administered intraperitoneally (ip) during and after tumor development. The lifes- pan and weight (30 days), number and type of leukocytes, number of tumor cells, volume of the solid and ascitic tumors, and the development of the tumor with tumoral cells pre-treated in vitro with the DCM fraction were analyzed after 7 days of treatment.

\section{Material and Methods}

\section{Extract, fractions and sample preparation}

Flowers and fresh leaves (600 g) of the plant were macerated with $6000 \mathrm{~mL}$ ethanol for 7 days, in the absence of light, and the extract obtained was reduced to $1 / 6$ of the initial volume, under vacuum, using a rotary evaporator (Quimis, São Paulo, SP, Brazil). Water $(600 \mathrm{~mL})$ was added to the crude extract obtained and the extract was submitted to liquid-liquid fractionation using solvents of increasing polarity. The fractions obtained were denoted: hexane (1.16 g), DCM (420 mg), ethyl acetate (560 mg), and water. After screening with all fractions, DCM showed high activity against the tumor cells (no tumor development was observed) and was selected for further investigation. An aliquot of the dry fractions was dissolved in saline using up to $2 \%$ Tween 80 and an ultrasonic bath (10 $\mathrm{min})$ to help dissolution at the following concentrations: 200 , $100,50,30,15$, and $5 \mathrm{mg} / \mathrm{kg}$ in a maximum final volume of $200 \mu \mathrm{L}$.

The prepared aliquoted samples were frozen until the day of application.

The DCM fraction is a dark-green semisolid material, its NMR spectra were recorded with a Bruker Avance 400 spectrometer (Rheinstetten, Germany).

\section{Animals}

Adult male inbred Swiss mice aged 8 weeks, maintained under standard environmental conditions, were used. The animals were fed a standard diet and received water ad libitum. The animals were used after an 
acclimatization period of 7 days, and the experiments were conducted in accordance with the Univali Ethics Committee for the treatment of laboratory animals.

\section{Ehrlich tumor}

Ehrlich ascitic tumor (EAT) derived from a spontaneous murine mammary adenocarcinoma was maintained in the ascitic form by passages in syngenic Swiss mice by weekly transplantation of $5 \times 10^{6}$ tumor cells (ip). The ascitic fluid was removed by opening the belly and collecting all the fluid with a sterile syringe. Ascitic tumor cell counts were carried out in a Neubauer hemocytometer using the Trypan blue dye exclusion method. The animals used for the experiment received $200 \mu \mathrm{L}$ of a suspension containing $5 \times 10^{6}$ tumor cells ip as described in Ref. 21.

\section{Animal treatment}

After ip implantation of tumor cells, seven groups of mice (6 mice per group) were treated with different concentrations of the DCM fraction $(200,100,50,30,15$, and 5 $\mathrm{mg} / \mathrm{kg}$, ip), the positive control group received 5-fluoro-uracil (5-FU) in $0.9 \%$ saline solution (20 mg/kg, ip) (22) and the negative control group received saline solution and $2 \%$ Tween ip in the same final volume. The body weights of the mice were measured daily until their death. The only animals to survive more than 30 days, those who received $5 \mathrm{mg} / \mathrm{kg}$, were sacrificed 30 days after the beginning of the treatment.

\section{Effect of the DCM fraction (5 $\mathrm{mg} / \mathrm{kg}$ ) on the ascitic tumor}

Seven groups of 6 mice each were used. Treatment was started immediately after inoculation of the tumor cells. Group 1 received $5 \mathrm{mg} / \mathrm{kg}$ DCM fraction, ip, group 2 received $20 \mathrm{mg} / \mathrm{kg} 5-\mathrm{FU}$, ip, group 3 re- ceived $0.9 \%$ saline, $i p$, group 4 received 5 $\mathrm{mg} / \mathrm{kg}$ DCM fraction by gavage, and group 5 received $0.9 \%$ saline by gavage. Group 6 started to be treated with the DCM fraction, $i p, 3$ days after inoculation of the Ehrlich ascitic tumor cells, and group 7 started to receive $0.9 \%$ saline, $i p, 3$ days after implantation of the tumor cells. After 7 days, the mice were sacrificed and all the ascitic fluid was harvested for volume measurement and ascitic tumor cell count by the Trypan blue dye exclusion method.

\section{Determination of the cytotoxicity of the DCM fraction $(5 \mathrm{mg} / \mathrm{kg})$ on Ehrlich ascitic tumor cells in vitro}

EAT cells $\left(5 \times 10^{6}\right)$ were pre-treated in vitro with the DCM fraction for $15 \mathrm{~min}$, and injected into the abdominal cavities of 6 mice (group 1). Group 2 received $5 \times 10^{6}$ EAT cells, ip, without pre-treatment. After 7 days, the mice were sacrificed and all the ascitic fluid was harvested for volume measurement and ascitic tumor cell count by the Trypan blue dye exclusion method.

\section{Determination of the effect of the DCM fraction $(5 \mathrm{mg} / \mathrm{kg})$ on solid tumor development}

Solid tumors were induced by injecting EAT cells, $5 \times 10^{6} /$ animal in $50 \mu \mathrm{L}$ subcutaneously into the hind paw of 5 groups (6 mice/group) of Swiss albino mice. Group 1 was treated with the DCM fraction (5 mg kg ${ }^{-1}$ animal $^{-1}$ ) ip and group 2 was treated with the same dose of the DCM fraction by gavage. Group 3 received $5 \times 10^{6}$ EAT cells per animal pre-treated with DCM and did not receive any further treatment. Group 4 received $0.9 \%$ saline $i p$, and group 5 received $0.9 \%$ saline by gavage. The animals were treated with the DCM fraction daily for 10 days, with the exception of group 3. Footpad volume was measured using a digital pachymeter. All treatments were daily. 


\section{Analysis of peritoneal leukocytes}

Six tumor-bearing mice per group were treated with $5 \mathrm{mg} / \mathrm{kg}$ of the DCM fraction, $i p$, the positive control group received 20 $\mathrm{mg} / \mathrm{kg} 5-\mathrm{FU}$, ip, and the negative control group received $0.9 \%$ saline, ip. After 30 days, the leukocytes were harvested from the peritoneal cavity with $5 \mathrm{~mL}$ saline. The peritoneal fluid was centrifuged, re-suspended in $200 \mu \mathrm{L}$ saline, distributed $(50 \mu \mathrm{L})$ on 24-well flat-bottom plates containing round glass coverslips $(15 \mathrm{~mm})$ for $1 \mathrm{~h}$ at room temperature, processed histologically, and stained with Harry's hematoxylin for microscopic observation. A single blind microscopic evaluation of five fields per coverslip $(\mathrm{N}=6)$ was performed using a reticule eyepiece with 100 quadrants. Based on nuclear shape, neutrophils, monocytes/macrophages and lymphocytes were counted by light microscopy at 100X magnification and the means for the five fields analyzed were calculated.

\section{Morphological analysis of the spleen}

The spleens from animals treated $i p$ for 30 days with the DCM fraction $(\mathrm{N}=4)$, from

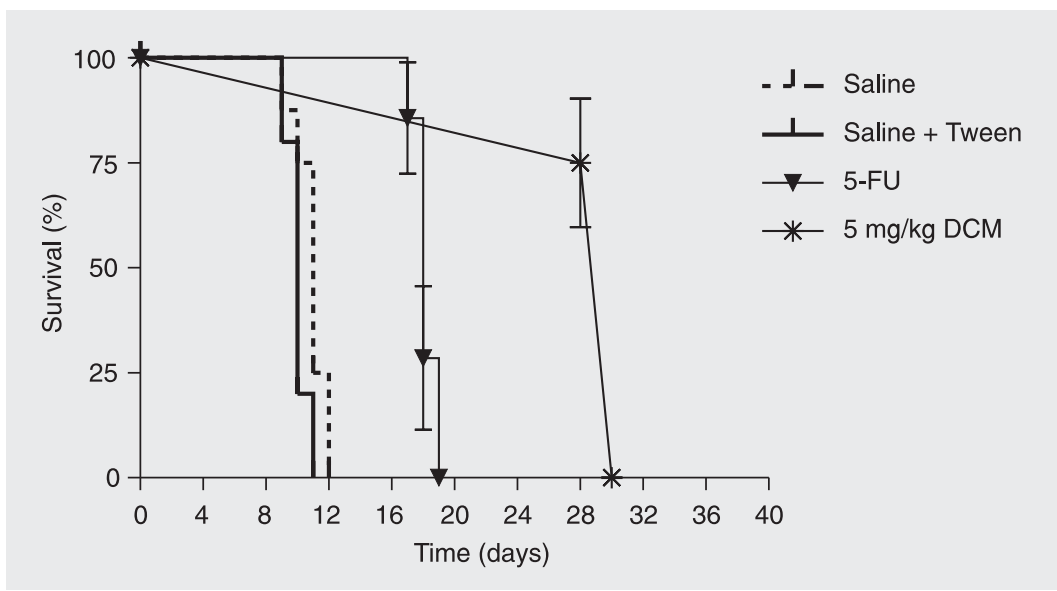

Figure 1. Kaplan-Meier survival curve of mice treated with saline, saline plus Tween, 5 fluoro-uracil (5-FU), or $5 \mathrm{mg} / \mathrm{kg}$ dichloromethane (DCM) fraction of the Vernonia scorpioides leaf extract ( $N=6$ in each group). Animals treated with the DCM fraction had a significantly longer lifespan than those treated with $5-\mathrm{FU}(\mathrm{P}<0.0001$, log-rank test). tumor-bearing animals after 7 days of survival, and from normal mice were removed and processed histologically. Sections were stained with hematoxylin-eosin for microscopic observation.

\section{Statistical analysis}

Data are reported as means \pm SD and were analyzed statistically by the Dunnett test and the F-test. The level of significance was set at $\mathrm{P} \leq 0.05$.

\section{Results}

Evaluation of the lifespan and body weight of the animals after treatment with different concentrations of the DCM fraction

Animals inoculated $i p$ with $5 \times 10^{6}$ EAT cells were divided into 5 treated groups $(\mathrm{N}=$ 6) receiving different concentrations of the DCM fraction $(5,30,50,100,200 \mathrm{mg} / \mathrm{kg})$, negative control group (saline solution and $2 \%$ Tween) and a positive control group treated ip with $20 \mathrm{mg} / \mathrm{kg}$ 5-FU (22). As shown in Figure 1 (longevity of the animals), the mice treated with the highest concentration $(200 \mathrm{mg} / \mathrm{kg})$ survived for only 12 $\mathrm{h}$, with longevity increasing proportionally with the subsequent decreasing concentrations. The animals that received $5 \mathrm{mg} / \mathrm{kg}$ of the DCM fraction survived the treatment and were sacrificed after 30 days. When the animals which had received higher doses were sacrificed, no tumor cells or ascitic fluid could be found in the abdominal cavities. Treatment with a $5 \mathrm{mg} / \mathrm{kg}$ dose of the DCM fraction caused a smaller loss of body weight during the 30-day period. A similar profile was observed for treatment with 5FU. Conversely, the body weight of the mice treated with saline increased, and higher concentrations of the DCM fraction induced loss of body weight. For these groups (control and 15, 30, and $50 \mathrm{mg} / \mathrm{kg}$ DCM fraction), the difference between the initial and 
final body weights was significant $(\mathrm{P}<0.05$; data not shown).

\section{Antitumor activity of the DCM fraction} immediately and after implantation of ascitic tumor cells

Figure 2A shows the effect of $i p$ administration of the DCM fraction against tumor cells, and ascitic volume when treatment was initiated immediately after tumor cell implantation. The result observed was the suppression of $100 \%$ of the tumor cells and ascitic volume when the animals were treated immediately after the inoculation of EAT cells, and around $80 \%$ tumor cells and $60 \%$ $(\mathrm{P}<0.001)$ ascitic volume, when ip treatment was started 3 days after tumor development (Figure 2B). The control groups treated with saline showed a larger volume of tumor and tumoral cells.

\section{In vitro cytotoxicity}

When the EAT cells were pre-treated in vitro with $5 \mathrm{mg} / \mathrm{kg}$ DCM fraction for $15 \mathrm{~min}$ and injected into the abdominal cavity, there was no tumor development. This suggests that this fraction had a direct cytotoxic activity against EAT cells.

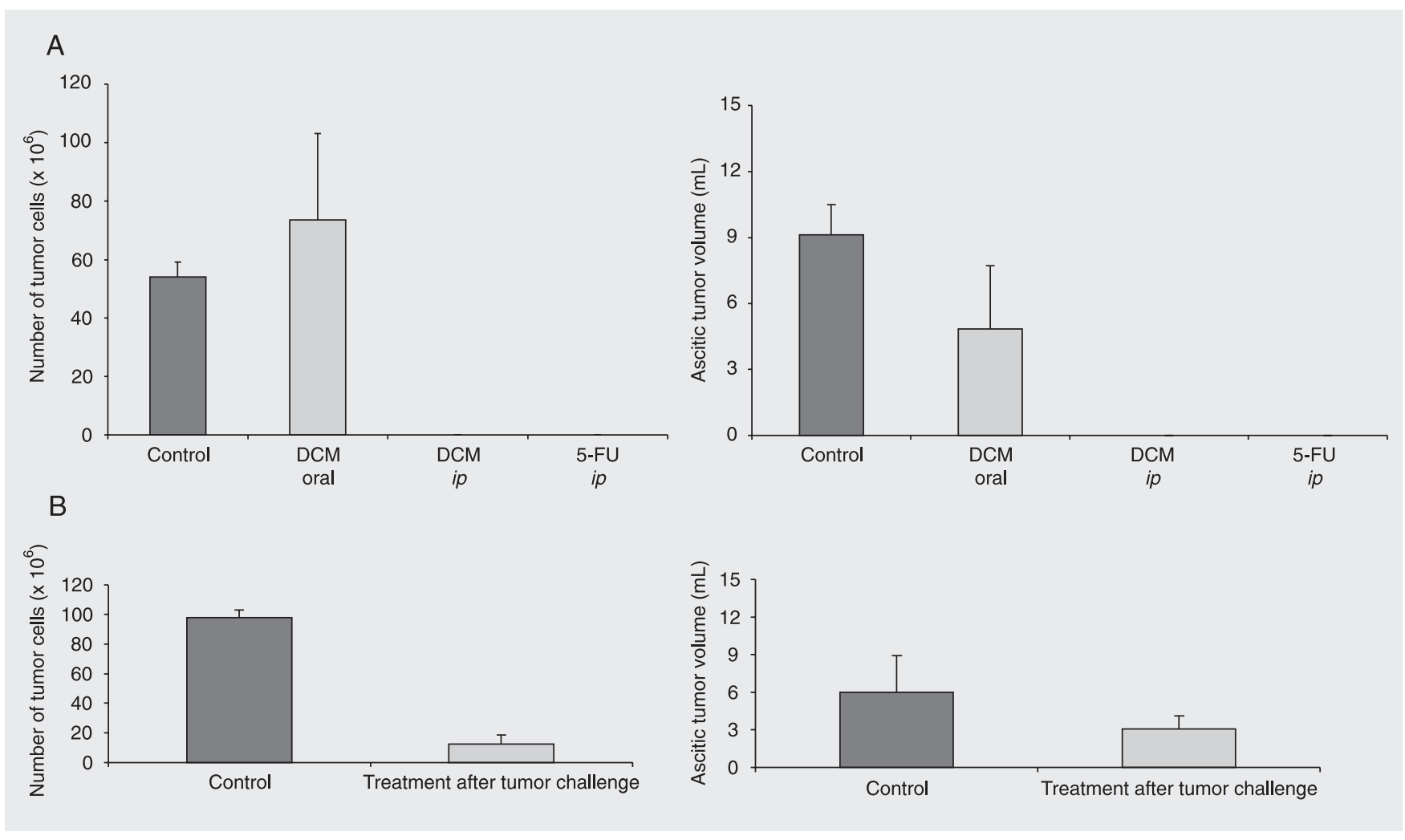

Figure 2. A, In vivo tumor cytotoxicity assay. The relative number of tumor cells and the ascitic volume were determined following daily oral and intraperitoneal (ip) administration once a day for 7 consecutive days of $5 \mathrm{mg} / \mathrm{kg}$ of the dichloromethane (DCM) fraction of the Vernonia scorpioides leaf extract, the standard reference drug 5 -fluoro-uracil (5-FU, $20 \mathrm{mg} / \mathrm{kg}$ ), and $0.9 \%$ saline (control) immediately after inoculation of $5 \times 10^{6}$ Ehrlich ascitic tumor cells. The mean values obtained from one experiment ( $N=6$ in each group) are presented. No significant difference in cell number was noted between the mice treated by gavage and the control group, as determined by analysis of variance using the F-test $(\mathrm{P} \leq 0.05)$. $B$, Effect of ip treatment with the DCM fraction after ascitic tumor challenge. Treatment was applied daily starting 3 days after the tumor challenge. The control group received $0.9 \%$ saline. The relative number of tumor cells and ascitic volume were calculated. The mean values obtained from one experiment $(\mathrm{N}=6$ in each group) are presented. A significant difference in number of cells was noted between the mice treated with the DCM fraction and the control group, as determined by analysis of variance using the F-test $(P \leq 0.05)$. 
Effect of DCM fraction on solid Ehrlich ascitic tumor development

Figure 3 shows the development of a solid tumor in the footpad after ip treatment with DCM. This fraction did not reduce the solid tumor volume when systemically inoculated, indicating that there was no indi-

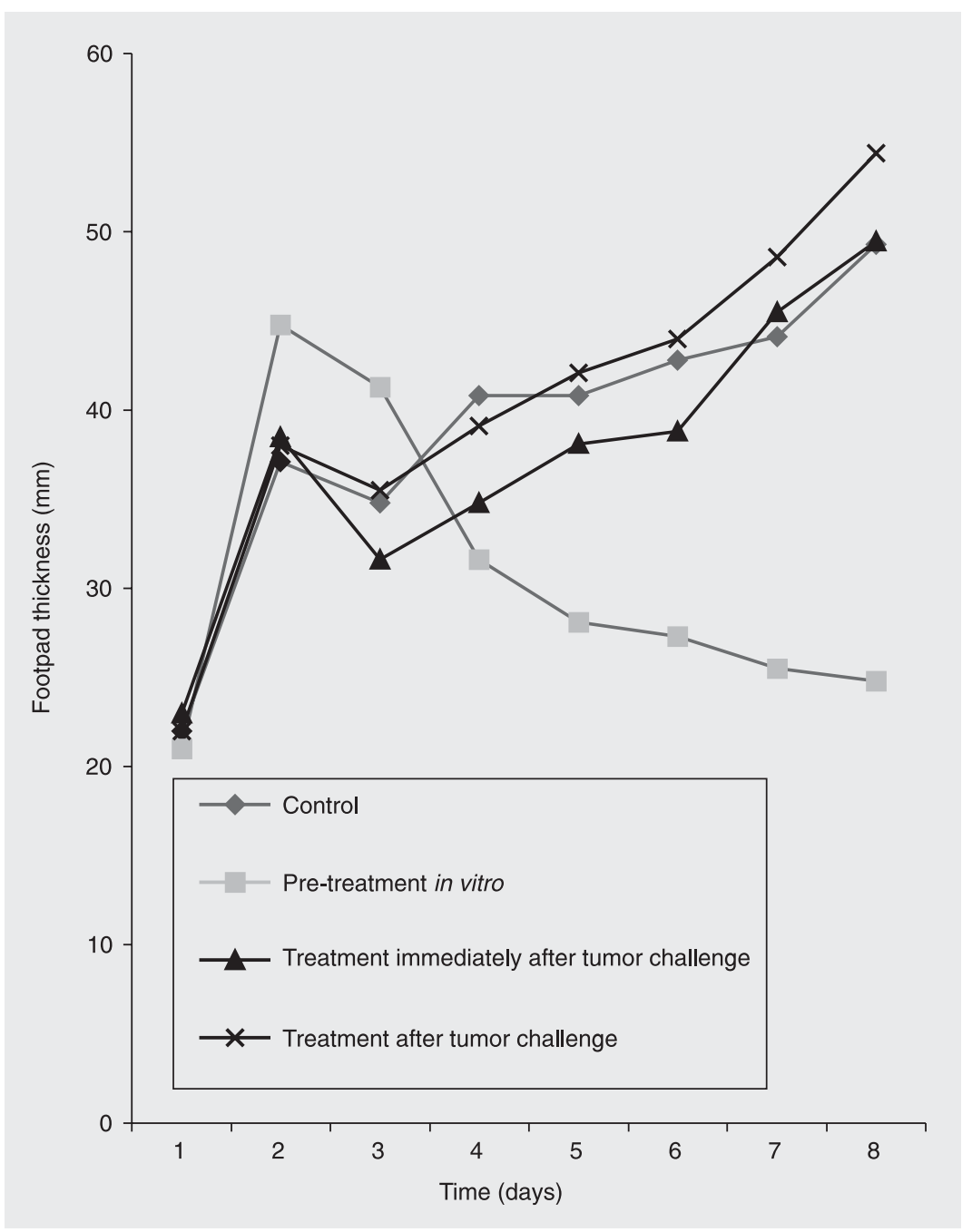

Figure 3. Effect of the dichloromethane (DCM) fraction of Vernonia scorpioides on solid tumor induced by Ehrlich's ascitic tumor (EAT) cells in mice. Tumor growth on the footpad was determined daily for 7 days following ip administration of the DCM fraction and $0.9 \%$ saline (control) immediately and 3 days after the tumor challenge. EAT cells pre-treated in vitro with the DCM fraction were also used for solid tumor induction. The mean values obtained from one experiment ( $\mathrm{N}=6$ in each group) are presented. No significant difference was noted between the treated groups and the control group, as determined by analysis of variance via the F-test $(P \leq 0.05)$. In vitro pre-treatment of the tumor cells with the DCM fraction inhibited tumor growth and after 3 days the solid tumor volume was significantly lower ( $\mathrm{P} \leq 0.05$, Dunnett test) than that of the saline-treated control. rect effect of DCM, probably due to the fact that the active compounds did not reach the tumor. Footpad thickness was measured for a period of 10 days and was not reduced when the DCM fraction was inoculated immediately or 3 days after the injection of tumor cells into the animals' paws compared to control. When the tumor cells were pretreated with the DCM fraction before implantation into the animals' footpad there was no solid tumor development.

\section{Analysis of peritoneal leukocytes}

Figure 4 shows the number of polymorphonuclear leukocytes present in the peritoneal cavity of EAT-bearing mice treated for 30 days with the DCM fraction and the standard reference drug 5-FU, compared with the number of cells present in the peritoneal cavity of normal mice treated with $0.9 \%$ saline. A significant difference was observed between the group treated with $5 \mathrm{mg} / \mathrm{kg}$ DCM fraction, the group treated with 5-FU, and normal mice as determined by analysis of variance via the F-test $(\mathrm{P} \leq 0.05)$. This profile is very different from the expected one, as shown by the lymphocyte count. The EAT-bearing mice treated with $0.9 \%$ saline died after 10 days.

The data in Figure 4 confirm the increased influx of leukocytes to the peritoneal cavity and illustrate the profile of inflammatory cells in each group. It was possible to compare the different types of leukocytes. Figure 4A shows the peritoneal cells, predominantly macrophages, from tumorbearing mice treated with the DCM fraction for 30 days, Figure 4B shows a reduced number of leukocytes from tumor-bearing animals treated with 5-FU, and Figure 4C shows the results for control animals.

\section{Morphological analysis of the spleen}

Significant increases in spleen size were observed in the mice treated with the DCM 
fraction compared to normal mice and mice that only received tumor cells. Histological examination of the spleens of mice treated with the DCM fraction demonstrated a significant increase in all white pulp areas, with an increased number of cells in the germinal center and lymphatic vessels.

\section{Discussion}

Plant-derived products such as vincristine, vinblastine, taxol, and many other substances in use today are excellent sources for the development of new anticancer chemotherapies. The Vernonia species belongs to the Asteraceae genus, which produces characteristic compounds such as sesquiterpene lactones with several biological properties, including anti-tumoral properties (23). In recent years, a significant number of papers have described the influence of these compounds on the growth of tumors. For example, parthenolide has been considered to be a cytotoxic or cytostatic drug and has been proposed as a complementary therapeutic drug in cancers with constitutively active NF- $\kappa \mathrm{B}$, which mediates the expression of pro-metastatic, pro-angiogenic, antiapoptotic, and multi-drug resistance genes (24).

Several studies focusing on the immunomodulatory effect of plant extracts have been conducted, showing a prominent role of extracts causing prophylactic growth inhibition of tumor cells $(25,26)$. Among the Vernonia species, some cytotoxicity has been described for isolated sesquiterpene lactones from $V$. cinerea (15), $V$. lasiopus (16) and $V$. amygdalina (27). Some active Vernonia extracts have also been found, such as the water-soluble extract of edible $V$. amygdalina leaves (9), and the water extract from the roots of V. kotschyana (20) and V. anthelmintica (10).

$V$. scorpioides has been studied in different biological tests and has shown cytotoxic effects in most of them. Previous studies have shown that the DCM and hexane fractions from the extract have fungicidal and bactericidal properties (2). Also, many Vernonia species are used as trypanocidal (28), antiplasmodial (29) and anthelmintic agents (30).

The results presented here confirm the toxic properties of the DCM fraction, a darkgreen semi-solid material rich in pigments that was characterized by infrared spectroscopy, showing strong absorption at ca. 1725 $\mathrm{cm}^{-1}$, characteristic of the presence of lactones. The NMR spectra showed the presence of acetyl and carbonyl radicals as indicated by intense signals at 168-170 and 20 ppm. Also some hydroxyl/methoxyl derivatives (68 and $55 \mathrm{ppm}$, intense peaks) and double bonds (124-128 ppm) are probably present. Acetylated sesquiterpene lactones
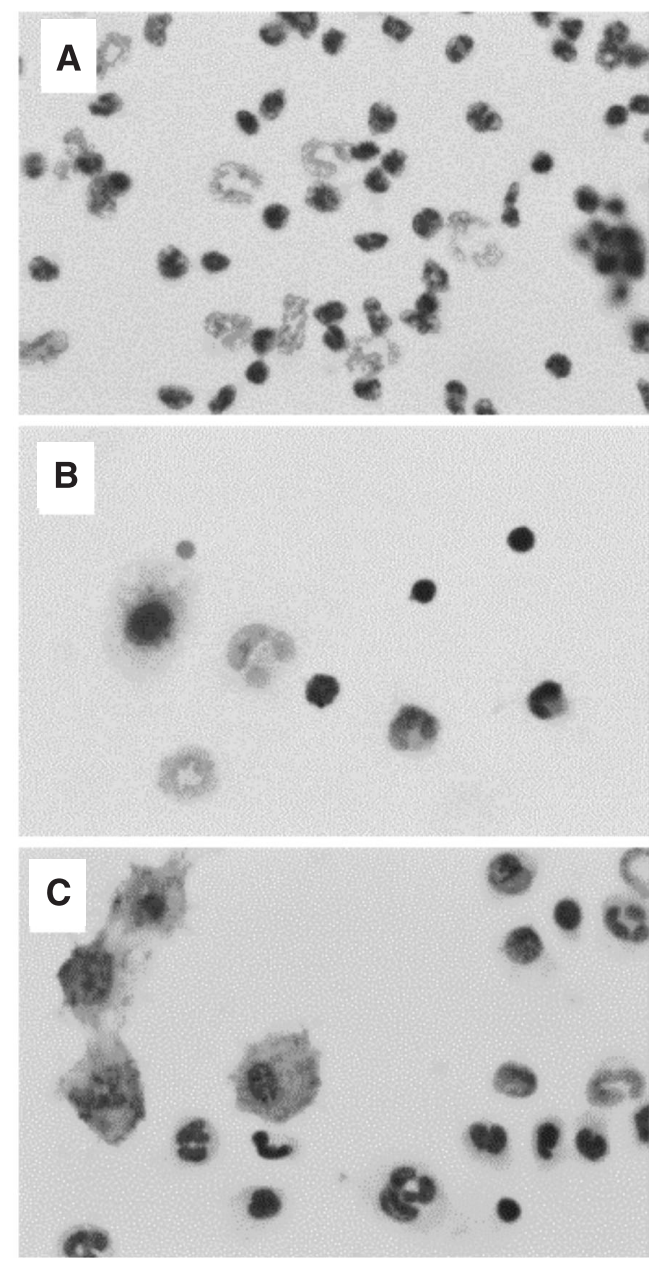

Figure 4. Mouse peritoneal leukocytes (hematoxylin staining). $A$, Tumor-bearing animals treated with the dichloromethane fraction of Vernonia scorpioides for 30 days. $B$, Tumor-bearing animals treated with 5 -fluoro-uracil. $C$, Control saline-treated animals. Magnification $=100 \mathrm{X}$. 
are commonly found in Vernonia species (15).

The DCM fraction totally inhibited tumor development when in direct contact with tumor cells, as also demonstrated by in vitro ip administration, in loco, to the ascitic tumor. Inoculation of the DCM fraction (5 $\mathrm{mg} / \mathrm{kg}$ ) increased the animals' lifespan and maintained their body weight throughout the 30 days of treatment. When applied immediately after inoculation of the tumor cells in vivo, it totally abolished tumor development, and when treatment was started 3 days after the tumor challenge, tumor development was decreased, supporting the existence of a probable antineoplastic activity.

Treatment by the oral or ip routes did not reduce the solid tumor volume, suggesting that some enzymatic routes can deactivate the systemic route. Another property that may exacerbate this cytotoxic activity is the ability of the fraction to increase neutrophil influx into the peritoneal cavity, unlike the conventional immune-suppressing profile of standard chemotherapy. When the tumor developed in the ascitic form, daily inoculation of the DCM fraction led to an increase in peritoneal leukocytes, and the tumor did not grow, with an increase in the animals' lifespan and maintenance of their body weight during the 30 days of treatment. These results show that, in addition to tumoricidal effects, the DCM fraction also has inflammatory activity. Sur et al. (31) showed that the seeds of Trigonella foenum graecum (Fenugreek) inhibited tumor growth by about $70 \%$ and also increased the influx of inflammatory cells to the peritoneal cavity. The present results have advanced our understanding of the antitumoral potential of the DCM fraction $V$. scorpioides. Investigations into the mechanism of action of the tumorreducing activity and also of the compounds responsible for the activity of the DCM fraction are currently in progress.

\section{Acknowledgments}

The authors are grateful to NMR laboratory, Chemistry Department, UFSCar, São Carlos, SP, Brazil, and to Maria Corrêa and Patrícia Matsuzaki for technical support with the animals and to Luciana Vizzoto (DQUFSCar) for recording the NMR spectra.

\section{References}

1. Cabrera AL, Klein RM. Compostas: Tribo: Vernoniae. FI llustr Catarin 1980; 3: 354-355.

2. Freire MFI, Abreu HS, Cruz LCH, Freire RB. Inhibition of fungal growth by extracts of Vernonia scorpioides (Lam.) Pers. Microbiology 1996; 27: 1-6.

3. Leite SN, Palhano G, Almeida S, Biavatti MW. Wound healing activity and systemic effects of Vernonia scorpioides extract in guinea pig. Fitoterapia 2002; 73: 496-500.

4. Monteiro MH, Gomes-Carneiro MR, Felzenszwalb I, Chahoud I, Paumgartten FJ. Toxicological evaluation of a tea from leaves of Vernonia condensata. J Ethnopharmacol 2001; 74: 149-157.

5. Mazumder UK, Gupta M, Manikandan L, Bhattacharya S, Haldar PK, Roy S. Evaluation of anti-inflammatory activity of Vernonia cinerea Less. extract in rats. Phytomedicine 2003; 10: 185-188.

6. Iwalewa EO, Iwalewa OJ, Adeboye JO. Analgesic, antipyretic, antiinflammatory effects of methanol, chloroform and ether extracts of Vernonia cinerea less leaf. J Ethnopharmacol 2003; 86: 229-234.

7. Gupta M, Mazumder UK, Manikandan L, Haldar PK, Bhattacharya $\mathrm{S}$, Kandar CC. Antibacterial activity of Vernonia cinerea. Fitoterapia 2003; 74: 148-150.
8. Izevbigie EB. Discovery of water-soluble anticancer agents from a vegetable found in Benin city, Nigeria. Exp Biol Med 2003; 228: 293298.

9. Izevbigie EB, Bryant JL, Walker A. A novel natural inhibitor of extracellular signal-regulated kinases and human breast cancer cell growth. Exp Biol Med 2004; 229: 163-169.

10. Lambertini E, Piva R, Khan MT, Lampronti I, Bianchi N, Borgatti M, et al. Effects of extracts from Bangladeshi medicinal plants on in vitro proliferation of human breast cancer cell lines and expression of estrogen receptor alpha gene. Int J Oncol 2004; 24: 419-423.

11. Howard CB, Stevens J, Izevbigie EB, Walker A, McDaniel O. Time and dose-dependent modulation of phase 1 and phase 2 gene expression in response to treatment of MCF-7 cells with a natural anti-cancer agent. Cell Mol Biol 2003; 49: 1057-1065.

12. Abosi $\mathrm{AO}$, Raseroka $\mathrm{BH}$. In vivo antimalarial activity of Vernonia amygdalina. Br J Biomed Sci 2003; 60: 89-91.

13. Muregi FW, Chhabra SC, Njagi EN, Lang'at-Thoruwa CC, Njue WM, Orago AS, et al. In vitro antiplasmodial activity of some plants used in Kisii, Kenya against malaria and their chloroquine potentiation effects. J Ethnopharmacol 2003; 84: 235-239. 
14. Krishna Kumari GN, Masilamani S, Ganesh MR, Aravind S, Sridhar SR. Zaluzanin D: a fungistatic sesquiterpene from Vernonia arborea. Fitoterapia 2003; 74: 479-482.

15. Kuo YH, Kuo YJ, Yu AS, Wu MD, Ong CW, Yang Kuo LM, et al. Two novel sesquiterpene lactones, cytotoxic vernolide-A and -B, from Vernonia cinerea. Chem Pharm Bull 2003; 51: 425-426.

16. Koul JL, Koul S, Singh C, Taneja SC, Shanmugavel M, Kampasi H, et al. In vitro cytotoxic elemanolides from Vernonia lasiopus. Planta Med 2003; 69: 164-166.

17. Campos M, Oropeza M, Ponce H, Fernandez J, Jimenez-Estrada M, Torres $\mathrm{H}$, et al. Relaxation of uterine and aortic smooth muscle by glaucolides D and E from Vernonia liatroides. Biol Pharm Bull 2003; 26: $112-115$.

18. Huang $\mathrm{Y}$, Ding $\mathrm{ZH}$, Liu JK. A new highly oxygenated flavone from Veronia saligna. Z Naturforsch [C] 2003; 58: 347-350.

19. Tchinda AT, Tane P, Ayafor JF, Connolly JD. Stigmastane derivatives and isovaleryl sucrose esters from Vernonia guineensis (Asteraceae). Phytochemistry 2003; 63: 841-846.

20. Nergard CS, Diallo D, Michaelsen TE, Malterud KE, Kiyohara H, Matsumoto $\mathrm{T}$, et al. Isolation, partial characterisation and immunomodulating activities of polysaccharides from Vernonia kotschyana Sch. Bip. ex Walp. J Ethnopharmacol 2004; 91: 141-152.

21. Matsuzaki P, Akisue G, Salgado Oloris SC, Gorniak SL, Zaidan Dagli ML. Effect of Pfaffia paniculata (Brazilian ginseng) on the Ehrlich tumor in its ascitic form. Life Sci 2003; 74: 573-579.

22. Christina AJ, Alwin JM, Heison Robert SJ, Kothai R, Chidambaranathan N, Muthumani P. Effect of Indigofera aspalathoides against Dalton's ascitic lymphoma. Fitoterapia 2003; 74: 280-283.

23. Blanco JG, Gil RR, Bocco JL, Meragelman TL, Genti-Raimondi S, Flury A. Aromatase inhibition by an 11,13-dihydroderivative of a sesquiterpene lactone. J Pharmacol Exp Ther 2001; 297: 10991105.

24. Miglietta A, Bozzo F, Gabriel L, Bocca C. Microtubule-interfering activity of parthenolide. Chem Biol Interact 2004; 149: 165-173.

25. Lin BF, Chiang BL, Lin JY. Amaranthus spinosus water extract directly stimulates proliferation of B lymphocytes in vitro. Int Immunopharmacol 2005; 5: 711-722.

26. Duong Van Huyen JP, Delignat S, Bayry J, Kazatchkine MD, Bruneval P, Nicoletti A, et al. Interleukin-12 is associated with the in vivo anti-tumor effect of mistletoe extracts in B16 mouse melanoma. Cancer Lett 2006.

27. Jisaka M, Ohigashi $H$, Takegawa K, Huffman MA, Koshimizu K. Antitumoral and antimicrobial activities of bitter sesquiterpene lactones of Vernonia amygdalina, a possible medicinal plant used by wild chimpanzees. Biosci Biotechnol Biochem 1993; 57: 833-834.

28. Tchinda AT, Tsopmo A, Tane P, Ayafor JF, Connolly JD, Sterner O. Vernoguinosterol and vernoguinoside, trypanocidal stigmastane derivatives from Vernonia guineensis (Asteraceae). Phytochemistry 2002; 59: 371-374.

29. Tona L, Cimanga RK, Mesia K, Musuamba CT, De Bruyne T, Apers $\mathrm{S}$, et al. In vitro antiplasmodial activity of extracts and fractions from seven medicinal plants used in the Democratic Republic of Congo. $J$ Ethnopharmacol 2004; 93: 27-32.

30. Hordegen P, Hertzberg H, Heilmann J, Langhans W, Maurer V. The anthelmintic efficacy of five plant products against gastrointestinal trichostrongylids in artificially infected lambs. Vet Parasitol 2003; 117: 51-60.

31. Sur P, Das M, Gomes A, Vedasiromoni JR, Sahu NP, Banerjee S, et al. Trigonella foenum graecum (fenugreek) seed extract as an antineoplastic agent. Phytother Res 2001; 15: 257-259. 